\title{
Highlights of the Annual Conference Meetings of the ACRL Board of Directors
}

The Board of Directors of the Association of College and Research Libraries met twice during the 1978 ALA Annual Conference in Chicago: on Monday, June 26, and on Wednesday, June 28.

\section{Division Representation on Council}

After consideration of the manner in which ACRL should handle the election of division Council representatives, the board moved that the Nominating Committee submit the names of two or more people who are currently or who have been president of the association in the last four years. If the past presidents are either currently on Council or otherwise unable to accept nomination, the Nominating Committee would then select candidates who are currently or who have been at-large board members in the last four years.

\section{Choice}

The board approved the recommendation of the Audiovisual Committee that the Editorial Board of Choice consider the inclusion of reviews of nonprint media in that publication, and that the editor submit to the Choice Editorial Board a feasibility report at the next Midwinter Meeting.

\section{Advertising Salary Ranges}

Despite the board's request that Council reject the resolution of the Committee on the Status of Women in Librarianship, Council did approve the recommendation requiring that salary ranges be listed in all ALA placement advertising. After discussion of possible alternative means of providing placement information to members, the board voted to request the reconsideration by $A L A$ Council of its action on advertising salaries and that, prior to Council review at 1979 ALA Midwinter, ACRL Council members and other interested persons be invited to attend an ACRL board meeting to discuss this matter more fully.

\section{Chapters}

The board approved the petition for chapter status by both the Florida Association of College and Research Libraries and the North Carolina chapter.

\section{Requirements for the Establishment of ACRL Discussion Groups}

The board adopted the recommendation submitted by the Planning Committee and referred to the ACRL Constitution and Bylaws Committee that the requirements be incorporated into the ACRL Bylaws and Constitution.

\section{Planning Committee}

The board approved the recommendations of the Planning Committee to: launch a campaign designed by specialists to increase membership; increase direct communications from ACRL headquarters on a periodic basis to members and occasionally to all college and research librarians to make the association tangible and real to them; promote regional meetings of $A C R L$ members; give the executive secretary a column in $C \dot{U} R$ News for direct communication to the membership and the regional chapters.

The board referred the committee's recommendation that "the Board will promote the development of state and regional chapters of ACRL, members of which must be members of ACRL" to the Chapters Committee for a progress report at Midwinter and a final report by the next Annual Conference.

The board voted that, as standard operating procedure for any future search for and appointment of an executive secretary, there would be a search committee composed of ACRL members, which would interview and make recommendations to the ALA executive director.

The board voted that action on the committee's recommendation on Priority 6 (pertaining to the future size and makeup of the ACRL board) of the Anderson Report be postponed until Midwinter Meeting of the board; and that the recommendation be published for the membership; and that there be debate in ACRL publication(s).

The board moved that the present system of standing committees, which are reviewed periodically by the Planning Committee to determine usefulness and need, be continued and that all ad hoc committees be established with a termination date, which could be extended where the need for continuation exists.

The board approved the committee's recommendation that Priority 8 (establishing procedures for accreditation of libraries and library school courses and programs related to research and postsecondary education libraries) of the Anderson Report be rejected on the grounds that ALA is the professional association recognized as the accreditation agency.

\section{University Library Standards}

Millicent Abell, reporting on the hearings devoted to the "Draft University Library Standards," said that three issues were raised in the meetings. Two concerns had to do with whether or not wording would be included to cover particular interests: bibliographic instruction and 
staff development and continuing education. The committee felt that both issues could be dealt with through modest additions to the wording. The other issue discussed pertained to the lack of quantification within the draft. In particular a need was expressed for further work in this area relating to performance standards and the development of a mechanism for gathering data for libraries that are covered by the standards but not included in the ARL data collection process.

The board approved and endorsed negotiation with ARL to include non-ARL-member university libraries in the annual collection of library statistics from ARL members.

Vote on Change of Location

\section{for ALA Midwinter Meeting}

The board endorsed the motion, which was to be proposed by George Bailey to ALA membership, to direct Council to reconsider its decision to move Midwinter out of Chicago. The motion failed on the floor of the membership meeting the following day.

\section{Office for Management Services/ Library Development Program}

The board moved that ACRL cooperate and actively participate with the Office of University Library Management Studies in developing the "Academic Library Program," and that the Executive Committee be empowered to make all appropriate arrangements.

\section{Academic Status Committee}

The board voted to postpone until the Midwinter Meeting the request that ACRL underwrite a pared-down version of the committee's proposed study of factors leading to the granting, retention, withdrawal, or denial of academic status for librarians in American four-year colleges and universities.

The board moved that the committee discuss with the ACRL Continuing Education Committee the implementation of a proposed education program on the nature of academic status for librarians and report back to the board not later than 1979 Annual Conference.

\section{Budget}

The board approved the ACRL budget with the understanding that some minor modifications will continue to be made by the Budget and Finance Committee.

\section{Publications Committee-}

\section{ACRI. Conference Papers}

The board voted to approve the committee's recommendation that planners of conferences may propose publication of papers to the editor of an appropriate ACRL publication. If this course is pursued, the proposal should be submitted well in advance of the conference; the ALA Publishing Services' guidelines for proceed- ings editors should be followed; and the editorial policies and review procedures of the respective ACRL publication's editorial board should be accepted and fulfilled. If the planners of the conference prefer, they may issue conference papers in the name of the conference of the sponsoring unit. Papers should be reproduced from typed copy submitted by the author at the opening of the conference and should be distributed to all conference participants within one month following the close of the conference. Costs of reproducing papers shall be covered by the budget for the conference. Copies of papers so reproduced shall also be available for purchase from the ACRL executive secretary's office.

\section{Copyright}

The board moved that ACRL endorse the text of a news release on copyright, which will be forthcoming in C\&RL News.

\section{ABSS Oberly Memorial Award}

The board accepted the recommendation of the Agriculture and Biological Sciences Section that the name of the Oberly Award be changed to "The Oberly Award for Bibliography in the Agricultural Sciences." The board approved the ABSS recommendation requesting that the ALA Endowment trustees provide estimates of Oberly Award endowment income alternatives.

\section{Anthropology Section}

The board voted to accept ANTS' recommendation that the president of the association be directed to write to the Harvard College Librarian to express ACRL's concern at the possible demise of the Peabody Museum Catalog published by G. K. Hall.

\section{Rare Books and Manuscripts Section}

The board accepted RBMS's recommendation to put the remainder of the 1978 preconference profits into a special fund for use in extraordinary speaker expenses anticipated for the 1980 international preconference, on the understanding that this was not to be considered a precedent.

The board accepted the section request for speedy (before Midwinter Meeting) publication in CURL News of the revised "Statement on Joint Access" prior to final presentation at Midwinter for adoption.

\section{Remarks}

Eldred Smith expressed his thanks to the board and his pleasure in working with it over the past year as president. A word of appreciation was expressed to Connie Dunlap for her many contributions to ACRL over the course of her years of service as a board member.

\section{President Farber Installed}

Eldred Smith handed over the gavel to Evan Farber. President Farber noted that it is the 
president's role to provide energy, imagination, and leadership to an organization, yet the responsibilities one has to one's own institution impose a finitude upon us all. The organization itself has to compensate for this, and President Farber expressed the need for cooperation and support from the committees and sections. He encouraged the committee and section chairs to do as much as possible, because it is through these groups that the association can design and implement meaningful programs. The thrust that is provided by the committees and sections is carried out by the executive secretary, and President Farber noted his having been impressed with the work of the executive secretary over the course of the past year.

\section{ACRL Officers for 1978/79}

Evan Ira Farber, head librarian at Earlham College (Lilly Library, Richmond, IN 47374), is the fortieth president of the Association of College and Research $\mathrm{Li}$ braries, a division of the American Library Association. During his term of office, Farber will preside over the ACRL Board of Directors and the ACRL Executive Committee. He will develop the plans for ACRL's major program meeting at the 1979 ALA Annual Conference in Dallas and will chair the ACRL Conference Program

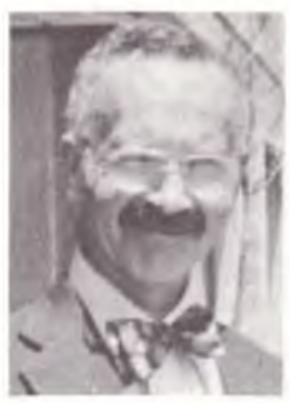

Evan Ira Farber
Planning Committee for that conference. The president serves as a member of all ACRL editorial boards and as an ex-officio member of all other units of the association.

As president of the division, Farber will represent ACRL on other ALA committees, including the ALA Dallas Conference Program Committee and the ALA Divisional Interests Special Committee. Farber also represents ACRL and ALA to other organizations, such as the American Council on Education.

In the past, Farber has served ACRL as chair of its College Libraries Section. He has served ALA as a member of the Library Administration Division's Buildings and Equipment Committee and the Non-Western Resources Committee. He was a Councilor for ALA from 1969 to 1971.

Le Moyne W. Anderson, director of libraries at Colorado State University (William E. Morgan Library, Fort Collins, CO 80523), is the newly elected vice-president/president-elect of the Association of College and Research Libraries. In the recent elections, Anderson received 1,349 votes, while Hendrik Edelman, newly appointed university librarian at Rutgers University, received 1,044 .
Anderson's prior service to ACRL has included a term on the Board of Directors, chair of the University Libraries Section, and membership on both the Goals, Priorities, and Structures and International Relations committees. In addition, he has served on the ALA Staff Organizations Round Table Steering Committee and the Library Research Round Table Nominations Committee.

As vice-president/president-elect of ACRL, Anderson will serve on the ACRL Board of Directors, the ACRL Executive Committee, and the ACRL Planning Committee. He will chair the ACRL Conference Program Planning Committee for the 1980 ALA Annual Conference in New York, and he will represent ACRL on the ALA Committee on Appointments, the ALA Budget Planning Assembly, and the ALA Conference Program Committee for the 1980 conference. At the close of the 1979 Annual Conference, he will become ACRL's forty-first president.

The results of the ACRL section elections follow. For each position, the elected candidate is listed first. The number of votes earned by each candidate is listed in parentheses.

\section{Agriculture and Biological SCIENCES Section}

Vice-Chair/Chair-Elect: Leila Moran, Chief, Reference Division, National Agricultural Library, Beltsville, MD 20705 (81); T. H. Milby, Science Librarian, Associate Professor of Bibliography, University of Oklahoma Library, Norman, OK 73019 (55).

Secretary (one-year term): Dolores B. Owen, Documents Librarian, University of Southwestern Louisiana Libraries, Lafayette, LA 70504 (73); Vladimir Micuda, Chief, Science and Technology Department, Pennsylvania State University Libraries, University Park, PA 16802 (61).

\section{ANTHROPOLOGY SECTION}

Vice-Chair/Chair-Elect: Anne K. Beaubien, Social Sciences Reference Librarian and Bibliographic Instructor, Hatcher Graduate Library, 